\title{
HUBUNGAN USIA DENGAN KEJADIAN ABORTUS PADA IBU DI RUANG PONEK RSUD JOMBANG
}

\author{
The Correlation Between With Abortion In Mother At Ponek Rsud Jonmbang \\ Anggun Prasetiya", Sestu R.D Andayayani, Fahruddin Kurdi \\ STIKES Pemkab Jombang \\ "Email : anggunprasetiya05.ap@ gmail.com
}

\begin{abstract}
ABSTRAK
Pendahuluan: Masalah kesehatan ibu hamil merupakan masalah yang perlu mendapatkan prioritas utama, hal ini menunjukan bahwa beberapa kehamilan tidak berakhir dengan kelahiran akan tetapi banyak yang mengalami abortus, kejadian ini dipicu karena beberapa faktor diantaranya adalah usia ibu, yang dimana usia sehat kehamilan yank baik antara 20-35 tahun, karena usia tersebut paling baik untuk kesehatan seorang ibu agar menghindari terjadinya abortus. Tujuan penelitian ini adalah untuk mengetahui hubungan usia dengan kejadian abortus. Metode: Desain penelitian ini Kuantitatif dengan metode analitik Retrospektif. Populasinya adalah semua ibu bersalin di Ruang PONEK RSUD Jombang rata-rata per bulan 185 orang. Variabel independen adalah usia sedangkan variabel dependen adalah Kejadian Abortus. Sampel yang digunakan sebanyak 46 orang dipilih dengan teknik non probability sampling dengan jenis purposive sampling. Pengumpulan data menggunakan data primer yaitu buku register pasien. Selanjutnya diuji Statistik menggunakan Chi Square dengan $\alpha(0,05)$. Hasil: Hasil uji statistic Chi-square didapatkan hasil 0,002 lebih kecil dari nilai $\alpha 0,05 \mathrm{H}_{1}$ diterima bahwa ada hubungan usia dengan kejadian abortus pada ibu di ruang PONEK RSUD Kabupaten Jombang. Pembahasan: Dari hasil penelitian diharapkan bagi tempat penelitian dan tenaga kesehatan perlu memperhatikan agar kejadian abortus tidak meningkat, serta untuk ibu yang hamil di usia $<20$ tahun dan $>35$ tahun agar lebih sering rutin memeriksakan kehamilannya agar tidak terjadi abortus dan masalah kehamilan lainnya.
\end{abstract}

Kata kunci: Kehamilan, Usia ibu, Abortus

\begin{abstract}
Introduction: The Health problem of pregnancy woman is need priority, this shows that many pregnancies is not always birthing a baby but some of them has abortion, this is caused many factors, one of them is a mother age, the best age of woman pregnancy is 20 - 35 years old, because it is the best age to avoid abortion. The purpose of this study is to determine the association of age with the incidence of abortion. Method: The design of study was Quantitative with Retrospective analytic method. The population was all maternity mothers in PONEK Room Jombang for about 185 people per month. The independent variable was age while the dependent variable was Abortus Genesis. The sample used 46 people selected with non probability sampling technique with purposive sampling type. Data collection used primary data which is in patient register book. Then tested statistic using Chi Square with $\alpha(0,05)$. Result: Chi-square statistic test results obtained 0.002 smaller than the value of $\alpha 0.05$ so it could be concluded that there was an age relationship with the incidence of abortion to the mother in the room of PONEK Jombang hospital. Discussion: From the result of the study wished to the place of study and healt works needed a big attention to the increasing of abortion, and for the pregnancy woman aged $<20$ yeard and $>35$ years frequen to chect her pregnancy to avoid abortion and other healt problems.
\end{abstract}

Keywords: Pregnancy, Age of mother, Abortion 


\section{PENDAHULUAN}

Masalah kesehatan ibu merupakan masalah yang perlu mendapat prioritas utama, karena sangat menentukan kualitas sumber daya manusia mendatang. Tingginya Angka Kematian Ibu (AKI) dan Angka Kematian Bayi (AKB), serta lambatnya penurunan angka kematian ibu dan bayi, menunjukkan bahwa pelayanan Kesehatan Ibu dan Anak (KIA) sangat mendesak untuk ditingkatkan baik dari segi jangkauan maupun kualitas pelayanan (Manuaba, 2010). Beberapa kehamilan berakhir dengan kelahiran tapi tidak jarang yang mengalami abortus.

Kejadian abortus sukar ditentukan karena abortus banyak yang tidak dilaporkan, kecuali bila sudah terjadi komplikasi. Menurut data Organisasi Kesehatan Dunia (WHO) persentase kemungkinan terjadinya abortus cukup tinggi. Sekitar 15-40 \% angka kejadian, diketahui pada ibu yang sudah dinyatakan positif hamil, dan 60-75\% angka abortus terjadi sebelum usia kehamilan mencapai 12 minggu (Lestariningsih, 2008). Faktor predisposisi dari abortus yaitu umur, paritas, jarak kehamilan, pekerjaan, dan riwayat obstetri jelek (Wiknjosastro, 2007).

Abortus adalah berakhirnya suatu kehamilan sebelum janin mencapai 500 gram atau umur kehamilan kurang dari 22 minggu atau buah kehamilan belum mampu untuk hidup di luar kandungan. Berdasarkan jenisnya abortus juga di bagi menjadi dua yaitu abortus spontan dan abortus provokantus (Sarwono, 2008).

Kasus abortus di dunia terjadi 20 juta tiap tahun dan 70.000 wanita meninggal karena abortus tiap tahunnya. Angka kejadian abortus di Asia Tenggara adalah 4,2 juta per tahun termasuk Indonesia, Sedangkan frekuensi abortus spontan di Indonesia adalah 10\%-15\% dari 6 juta kehamilan setiap 1,5 juta setiap tahunnya, 2500 orang diantaranya berakhir dengan kematian (Anshor, 2006). Laporan Riset Dasar Kesehatan (RisKesDas) tahun 2010 menyebutkan bahwa presentase abortus dalam periode lima tahun terakhir adalah sebesar $4 \%$ pada perempuan pernah menikah usia 10-59 tahun.
Menurut data Dinas Kesehatan Kabupaten Jombang, angka kejadian abortus tahun 2014 pada triwulan pertama 147, pada triwulan kedua 118, pada triwulan ketiga 122, dan pada triwulan keempat sebanyak 136. Sedangkan menurut data yang di dapat dari rekam medik Rumah Sakit Daerah Jombang (RSUD Jombang) jumlah yang didapat pada penderita abortus selama tahun 2014 yaitu pada abortus imminens sebanyak 5, abortus insipient sebanyak 1, abortus tertunda (missed abortion) sebanyak 9, abortus komplit sebanyak 4, dan pada abortus inkomplit sebanyak 68 wanita (Yulichati, 2014). Berdasarkan data yang diperoleh dari Ruang PONEK RSUD Jombang pada tanggal 13 januari 2017 didapatkan bahwa pada tahun 2016 terdapat 117 kejadian abortus, hal ini menunjukan bahwa dalam jangka 2 tahun ini jumlah ibu abortus di RSUD Jombang mengalami peningkatan dibandingkan dengan kejadian abortus pada tahun 2014 yang berjumlah $87 \mathrm{ibu}$ dengan abortus.

Umur seorang ibu memiliki peranan yang penting dalam terjadinya abortus. Semakin tinggi umur maka risiko terjadinya abortus semakin tinggi pula. Hal ini seiring dengan naiknya kejadian kelainan kromosom pada ibu yang berusia 35 tahun. Wanita hamil kurang dari 20 tahun juga dapat merugikan kesehatan ibu, Karena pada ibu usia dibawah 20 tahun risiko terjadinya abortus kurang dari $2 \%$. Risiko meningkat $10 \%$ pada usia ibu lebih dari 35 tahun dan mencapai 50\% pada usia ibu lebih dari 45 tahun. Peningkatan risiko abortus ini diduga berhubungan dengan abnormalitas kromosom pada wanita usia lanjut (Cunningham, 2012).

Agar kejadian abortus bisa dihindari, maka untuk itu perlu dilakukan upaya manajemen pencegahan kehamilan melalui program KB (Keluarga Berencana) pada kelompok usia kurang dari 20 tahun dan lebih dari 35 tahun. Pada usia 20 tahun banyak upaya yang bisa dilakukan untuk menunda terjadinya kehamilan. Pendewasaan usia menikah merrupakan salah satu alternative solusi. Upaya lain yang bisa dilakukan adalah dengan 
program $\mathrm{KB}$, baik $\mathrm{KB}$ alami maupun $\mathrm{KB}$ dengan menggunakan alat kontrasepsi. Pengetahuan yang mencukupi tentang organ reproduksi, siklus mentruasi dan alat reproduksi alat kontrasepsi, pertumbuhan dan perkembangan janin akan memudahkan PUS (Pasangan Usia Subur) untuk memilih metode KB yang sesuai. Padaa usia 35 tahun keatas pencegahan kehamilan dengan menggunakan metode $\mathrm{KB}$ yang sesuai merupakan salah satu solusi. Disamping itu perencanaan kehamilan dan perencanaan waktu menikah juga konsep piker tentang nilai anak, jenis kelamin, akan bermanfaat untuk mencegah terjadinya kehamilan pada usia 35 tahun keatas (Rukiyah, 2010).

Berdasarkan uraian diatas peneliti tertarik untuk melakukan penelitian mengenai hubungan usia dengan kejadian abortus pada ibu, karena untuk sementara ini penelitian masih jarang diteliti dan berdasarkan data yang didapatkan jumlah abortus pada ibu di Ruang Ponek RSUD Jombang meningkat.

\section{METODE PENELITIAN}

Desain yang digiunakan dalam penelitian ini adalah analitik korelasional yang mengkaji hubungan antara variabel dengan menggunakan pendekatan retrospektif yaitu rancangan bangun dengan melihat ke belakang dari suatu kejadian yang berhubungan dengan kejadian kesakitan yang diteliti (Hidayat, 2010). Populasinya adalah semua ibu bersalin di Ruang PONEK RSUD Jombang rata-rata per bulan 185 orang Sampel yang digunakan sebanyak 46 orang dipilih dengan teknik non probability sampling dengan jenis purposive sampling yaitu penentuan sampling yang dilakukan dengan pertimbangan atau kriteria-kriteria tertentu (sujarweni, 2014)

Sampel diambil dengan memenuhi kriteria inklusi dan eksklusi.

a. Kriteria inklusi dari penelitian ini adalah sebagai berikut :

1. Ibu yang bersalin di Ruang PONEK RSUD Jombang
2. Ibu yang Abortus di Ruang PONEK RSUD Jombang

3. Ibu dengan data yang lengkap

4. Buku laporan rekam medik 1 bulan terakhir.

b. Kriteria eksklusi dari penelitian ini terdiri dari:

1. Data laporan rekam medik ibu bersalin yang tidak lengkap

2. Ibu melahirkan dengan komplikasi penyakit menular

3. Ibu melahirkan dengan infeksi (Virus Toxoplasma, rubella, dll).

Penelitian ini dilaksanakan di Ruang PONEK RSUD Jombang pada tanggal 06 April - 12 April 2017.

\section{HASIL PENELITIAN}

Hasil penelitian yang diperoleh dalam penelitian Hubungan usia dengan kejadian abortus pada ibu di Ruang PONEK RSUD Jombang Pada tanggal 06 April - 12 April 2017 adalah sebagai berikut:

Tabel 1 menunjukan bahwa dari 46 responden sebagian besar $(80,4 \%)$ berumur 20-35 sebanyak 37 responden. Dan dari 46 responden sebagian besar $(63,0 \%)$ adalah multipara (persalinan ke 2-4).

Tabel 2 menunjukan bahwa dari 46 responden sebagian besar $(80,4 \%)$ miliki kriteria usia tidak beresiko sebanyak 37 responden.

Tabel 3 menunjukan bahwa dari 46 responden sebagian besar $(80,4 \%)$ tidak mengalami abortus.

Tabel 4 didapatkan bahwa dari 9 orang responden yang memiliki usia beresiko 5 mengalami abortus. 
Tabel 1 Distribusi frekuensi responden berdasarkan usia di Ruang PONEK RSUD Jombang.

$\begin{array}{lll}\text { Keterangan } & \text { Frekuensi } & \text { Presentase (\%) }\end{array}$

Umur Ibu

$\begin{array}{ccc}<20 & 2 & 4,3 \\ 20-35 & 37 & 80,4 \\ >35 & 7 & 15,2 \\ & & \\ \text { Primipara } & 14 & 30,4 \\ \text { Multipara } & 29 & 63,0 \\ \text { andemultipara } & 3 & 6,5\end{array}$

Sumber : Data Sekunder Bulan Maret 2017

Tabel 2 Distribusi Frekuensi responden berdasarkan umur ibu di Ruang PONEK RSUD Jombang Bulan Maret 2017.

\begin{tabular}{ccc}
\hline Umur Ibu & Frekuensi & Presentase (\%) \\
\hline Tidak Beresiko & 37 & 80,4 \\
Beresiko & 9 & 19,6 \\
Total & 46 & 100,0 \\
\hline
\end{tabular}

Sumber : Data Sekunder Bulan Maret 2017

Tabel 3 Distribusi Frekuensi responden berdasarkan umur ibu di Ruang PONEK RSUD Jombang Bulan Maret 2017.

\begin{tabular}{ccc}
\hline Abortus & Frekuensi & Presentase (\%) \\
\hline Tidak Abortus & 37 & 80,4 \\
Abortus & 9 & 19,6 \\
Total & 46 & 100,0 \\
\hline
\end{tabular}

Sumber : Data Sekunder Bulan Maret 2017

Tabel 4 Tabulasi Silang Antara Usia dengan Kejadian Abortus pada Ibu Di Ruang PONEK RSUD Jombang Bulan Maret 2017.

\begin{tabular}{|c|c|c|c|c|c|c|}
\hline \multirow{3}{*}{ Usia ibu } & \multicolumn{4}{|c|}{ Kejadian Abortus } & \multirow{2}{*}{\multicolumn{2}{|c|}{ Total }} \\
\hline & Tida & bortus & & & & \\
\hline & $\mathrm{f}$ & $\%$ & $\mathrm{~F}$ & $\%$ & $\mathrm{f}$ & $\%$ \\
\hline Tidak Beresiko & 33 & 39,2 & 4 & 10,8 & 37 & 100 \\
\hline Beresiko & 4 & 14,4 & 5 & $i 5,6$ & 9 & 100 \\
\hline
\end{tabular}

Sumber : Data Primer Bulan Maret 2017

Berdasarkan hasil uji Chi-square dengan menggunakan program software SPSS 20 for windows, menunjukkan bahwa hasil signifikan atau nilai probalitas atau $\rho$ value sebesar $(0,002)$ lebih kecil dari nilai $\alpha(0,05)$ atau $(\mathrm{p}<\alpha)$, maka Ho ditolak dan $\mathrm{H} 1$ diterima sehingga dapat disimpulkan bahwa ada hubungan usia dengan kejadian abortus pada ibu di ruang PONEK RSUD Kabupaten Jombang.

Berdasarkan hasil uji tersebut juga dapat diketahui tingkat hubungan antara dua variabel dengan ditunjukkan nilai korelasi 0,408 yang terletak antara 0,4000,599 dengan tingkat hubungan sedang atau bisa dikatakan cukup. 


\section{PEMBAHASAN \\ Usia Ibu}

Tabel 4.1 menunjukan bahwa hampir seluruhnya $(80,4 \%)$ responden usia $20-35$ tahun yang berjumlah 37 orang. Umur yaitu usia individu yang terhitung mulai saat dilahirkan sampai saat berulang tahun, Semakin cukup umur seseorang maka tingkat kematangan dan kekuatan seseorang akan lebih matang dalam berfikir dan bekerja (Nursalam,2001). Menurut BKKBN usia yang ideal untuk hamil dan melahirkan yaitu 20-30 tahun, lebih atau kurang dari usia tersebut adalah beresiko karena pada masa hamil banyak terjadi perubahan-perubahan baik secara fisik maupun psikologi untuk itu diperlukan persiapan dalam menghadapi masa kehamilan tersebut (Manuaba 2010). Usia responden paling banyak adalah ibu dengan kategori usia produktif sehingga terhindar dari resiko-resiko yang ada dalam kehamilan dan bagi seorang ibu sudah siap untuk menerima kehamilan dengan baik.

Berdasarkan data yang diperoleh, diketahui bahwa dari sebagian besar $(63,0 \%)$ sebanyak adalah multipara (persalinan ke 2-4). Hal ini beresiko karena pada ibu dapat timbul kerusakan-kerusakan pada pembuluh darah dinding uterus yang mempengaruhi sirkulasi nutrisi ke janin (Manuaba, 2010). Paritas bisa dipengaruhi oleh ibu yang tidak mengatur jarak kelahiran dan jumlah anak yang dilahirkan, paritas juga merupakan salah satu penyebab masalah-masalah dalam kehamilan karena jika seorang ibu yang sering melahirkan mempunyai resiko terhadap kesehatannya dan juga bagi kesehatan anaknya.

\section{Kejadian Abortus}

Berdasarkan tabel 4.5 didapatkan bahwa dari 9 orang responden yang memiliki usia beresiko 5 mengalami abortus. Dampak selama kehamilan usia muda yang dapat terjadi adalah abortus, dimana abortus dapat terjadi secara sengaja atau tidak sengaja akibat terkejut, cemas dan stres. Matangnya alat reproduksi terutama rahim yang belum siap dalam suatu proses kehamilan (Lestari dkk,2013). Dalam kehamilan umur seorang ibu nampaknya memiliki peranan yang penting dalam terjadinya abortus. Semakin tinggi umur maka risiko terjadinya abortus semakin tinggi pula. Hal ini seiring dengan naiknya kejadian kelainan kromosom pada Ibu yang berusia 35 tahun dan wanita hamil kurang dari 20 tahun dapat merugikan kesehatan ibu maupun pertumbuhan dan perkembangan janin karena belum matangnya alat reproduksi untuk hamil. Penyulit pada kehamilan remaja $(<20$ tahun) lebih tinggi dibandingkan kurun waktu reproduksi sehat antara 20-30 tahun. Keadaan tersebut akan makin menyulitkan bila ditambah dengan tekanan (stress) psikologi, sosial, ekonomi, sehingga memudahkan terjadinya abortus (Manuaba, 2010). Masalah kehamilan pada ibu memang sangat erat kaitannya dengan usia seorang ibu saat hamil maupun melahirkan, untuk itu ibu yang memiliki usia yang relative tua maupun yang muda bisa rentan akan terjadinya abortus dan masalah komplikasi lainnya yang rentan terjadi pada ibu maupun janinnya.

Berdasarkan dari peneltian menunjukan bahwa dari 46 responden yang mengalami abortus 9 dan yang tidak abortus 37 orang. Abortus banyak terjadi pada kehamilan maternal berisiko tinggi jika terlalu banyak anak, umur kurang dari 20 tahun dan lebih dari 35 tahun, riwayat obstetrik, jumlah anak lebih dari 4 anak, serta jarak kehamilan kurang dari 2 tahun dan pekerjaan (Wiknjosastro, 2010).

Kejadian abortus memang dapat dipengaruhi oleh banyak faktor seperti jarak kehamilan, paritas, dan juga riwayat abortus sebelumya, akan tetapi salah satunya umur ibu juga sangat mempengaruhi seorang ibu rentan untuk terjadi abortus, dan menurut data penelitian $19,6 \%$ ibu yang abortus adalah mereka yang termasuk dalam kriteria umur yang beresiko.

\section{Hubungan Antara Usia dengan Kejadian Abortus pada Ibu}

Hasil penelitian menunjukan bahwaa ibu yang mengalami Abortus lebih banyak terjadi pada ibu yang memiliki usia beresiko $55,6 \%$ dibandingkan pada ibu yang memiliki usia tidak beresiko $10,8 \%$. 
Berdasarkan hasil uji Chi-square menggukan program software SPSS 20 for windows, menunjukkan bahwa hasil hitung signifikan atau nilai probalitas atau $\rho$ value $(0,002)$ lebih kecil dari nilai $\alpha(0,05)$ atau $(\mathrm{p}<\alpha)$, maka Ho ditolak dan H1 diterima sehingga dapat disimpulkan bahwa ada hubungan usia dengan kejadian abortus pada ibu di ruang PONEK RSUD Kabupaten Jombang. Berdasarkan hasil uji tersebut juga dapat diketahui tingkat hubungan antara dua variabel dengan ditunjukkan nilai korelasi 0,408 yang terletak antara 0,400-0,599 dengan tingkat hubungan sedang atau bisa dikatakan cukup.

Usia dapat mempengaruhi kejadian abortus karena pada usia kurang dari 20 tahun belum matangnya alat reproduksi untuk hamil sehingga dapat merugikan kesehatan ibu maupun pertumbuhan dan perkembangan janin, sedangkan abortus yang terjadi pada usia lebih dari 35 tahun disebabkan berkurangnya fungsi alat reproduksi, kelainan pada kromosom dan penyakit kronis (Manuaba, 2010).

Menurut Manuaba (2010), bahwa secara psikologi sebelum tercapainya emosi dan kejiwaan yang cukup dewasa akan berpengaruh terhadap penerimaan kehamilan yang akhirnya berdampak pada pemeliharaan dan perkembangan bayi yang dikandungnya. Memang benar resiko akan bertambah seiring bertambahnya umur saat hamil, tetapi bukan tidak mungkin ibu yang berumur $<20$ tahun atau $>35$ tahun akan menjalani kehamilan yang sehat dan melahirkan yang sempurna, begitu pula sebaliknya ibu yang umur 20-35 tahun bukan tidak mungkin menjalani kehamilan yang tidak sehat dan melahirkan bayi yang tidak sempurna. Hal ini ditunjang dengan persiapan lebih matang, informasi yang lebih lengkap dan informasi kehamilan resiko tinggi. Ibu yang dikategorikan memiliki resiko tinggi dalam kehamilan dan persalinan biasanya lebih berhati-hati terhadap kehamilanya dibandingkan ibu yang reproduktif. Mereka akan mencari dan menyerap informasi dengan baik tentang kondisi-kondisi dan resiko-resiko yang mungkin terjadi pada kehamilan mereka. Mereka juga cenderung mempersiapkan diri mereka lebih baik sebelum hamil, jika kehamilan yang diinginkan.

Dalam teori Ramona T. mercer pada pencapaian peran seorang ibu di pengaruhi oleh beberapa faktor yaitu : faktor ibu, faktor ayah, faktor bayi, dan faktor lainnya. Dalam faktor ibu disebutkan bahwa banyak komponen yang dapat mempengaruhi salah satunya adalah Usia ibu dalam memcapai perannya (Yulifah dkk, 2013).

Pada kenyataannya hal ini memang benar bahwa usia sangat berpengaruh terhadap terjadinya gangguan pada kehamilan yang salah satunya adalah pada Abortus, karena usia ibu $<20$ tahun yang rentan lebih muda karena belum matangnya organ reproduksi sehingga kemungkinan besar gangguan kehamilan akan muda terjadi pada ibu maupun janin yang dikandung, dan apabilan umur ibu yang relative lebih tua atau $>35$ tahun juga memiliki resiko terhadap komplikasi kehamilan yang berakibat dari menurunnya fungsi organ reproduksi sehingga bisa beresiko abortus. Hasil penelitian yang dilakukan sesuai teori keperawatan Ramona $\mathrm{T}$ Mercer bahwa usia sangat berpengaruh dan termasuk komponen yang utama dalam pencapaian peran ibu, Sehingga dapat disimpulkan bahwa ada hubungan antara usia dengan kejadian abortus pada ibu hamil.

\section{KESIMPULAN DAN SARAN Kesimpulan}

a. Usia Ibu bersalin di Ruang PONEK RSUD Jombang sebagian besar adalah tidak resiko tinggi.

b. Kejadian Abortus di Ruang PONEK RSUD Jombang hampir seluruhnya tidak terjadi Abortus.

c. Ada hubungan antara usia dengan kejadian abortus pada ibu di Ruang PONEK RSUD Jombang, yakni semakin usia ibu beresiko maka semakin tinggi kejadian abortus daripada ibu yang tidak memiliki usia beresiko. 


\section{Saran}

\section{Teoritis}

Diharapkan hasil penelitian ini dapat dijadikan acuan atau materi tentang Abortus pada kehamilan.

\section{Praktis}

a. Bagi pelayanan keperawatan

Pelayanan kesehatan khususnya pada kesehatan ibu hamil sangat diperhatikan agar tidak akan terjadi adanya abortus yang semakin meningkat dan berulang, maka dari itu perlu adanya pemberian health education pada ibu yang hamil yang memiliki usia yang beresiko, serta pemberian papan bener pada rumah sakit maupun ditempat pelayanan kesehatan lainnya.

b. Bagi Institusi

Institusi diharapkan lebih banyak memfasilitasi materi tentang keperawatan maternitas.

c. Bagi Responden

Ibu hamil disarankan agar bisa mengatur usia untuk persiapan kehamilan, dan untuk seorang ibu yang sudah terlanjur hamil di usia yang beresiko agar mengaja baik kesehatannya, seta untuk rutin memeriksakan kehamilannya ke pelayanan kesehatan terdekat agar terhindar dari masalah kehamilan salah satunya abortus.

\section{DAFTAR PUSTAKA}

Achadiat, M.chridiono. 2004 Prosedur Tetap Obstetri \& Ginekologi, Cetakan I . Jakarta : EGC.

Arikunto, 2006. Prosedur Penelitian Suatu Pendekatan Praktik. Jakarta : Rineka Cipta.

Atikah P, Siti M. Nutrisi Janin dan ibu hamil. Yogyakarta: Nuha Medika, 2010: 88-148.

Cahyaningrum, S.ST dkk. 2014. Hubungan Umur Ibu Hamil Dengan Kejadian Abortus di RSUD Ambarawa Tahun 2014 http://perpusnwu.web.id/karyailmi ah/documents/4036.pdf.diakses 20/12/16.

Chandra Wulandari dan nasikhah Hubungan Usia Ibu dengan Kejadian Abortus Inkomplete di
Rumah Sakit Palang Biru

Kutoarjo. 20/01/2017

Cunningham, 2012. Obstetri William. Edisi Kedelapan Belas.

FK UNPAD, 2005. Obstetri Patologi Ilmu Kesehatan Reproduksi : Bagian obstetri dan Ginekologi Fakultas Kedokteran Jakarta : EGC.

Hadijanto, B. 2008. Pendarahan pada Kehamilan Muda In: Ilmu Kebidanan Sarwono Prawirohardjo. Jakarta, PT Bina Pustaka Sarwono Prawirohardjo : 459-473.

Hidayat, A. Aziz Alimul. 2008. Riset Keperawawatan dan Teknik Penulisan Ilmiah. Jakarta : Salemba Medika.

2014. Metode Penelitian Keperawatan dan Teknik Analisis. Jakarta: Salemba Medika.

Krisnadi. Sofie R,dkk (2009) Prematuritas. Bandung : PT Refika Aditama. Dalam jurnal Delima Azhar Vol 2, No.1 Agustus 2016 - Januari 2017: 6670. Hubungan kehamilan usia dini dengan kejadian persalinan prematur Di ruang bersalin rumah sakit ibu dan anak paradise Tahun 2015.

Lestari, TW, Elisa U, Suparmi, 2013. Buku Ajar Kesehatan Reproduksi Berbasis Kompetensi. Jakarta: EGC. Dalam jurnal Anita Dewi Lieskusumastuti. Faktor risiko yang berhubungan dengan kejadian Abortus spontan di rsu pku muhammadiyah delanggu Tahun 2016.

Manuaba, Ida Ayu Chandranita dkk. 2009. Memahami Kesehatan Reproduksi Wanita, Edisi 2. Jakarta : EGC

2010. Ilmu Kebidanan, Penyakit Kandungan, dan KB untuk Pendidikan Bidan. Edisi 2. Jakarta: EGC.

2012. Ilmu kebidanan, penyakit kandungan dan KB. EGC : Jakarta. 
Manuaba, dkk. 2010. Pengantar Kuliah Obstetri. Jakarta : EGC

Maulana, M. 2016 Panduan Lengkap Kehamilan, Edisi Cetakan : IV. Sleman, Jogjakarta : Katahati.

Nugroho, taufan. 2010. Buku ajar obstetric. Yogjakarta : Nuha Medika

Nursalam. 2016 Metode Penelitian Ilmu Keperawatan, Edisi Cetakan :IV. Jakarta: Salemba Medika.

Prawirohardjo, S. 2006. Pelayanan Kesehatan Maternal dan Neonatal. Jakarta : Yayasan Bina Pustaka

2009. Buku Panduan Praktis Pelayanan Kesehatan Maternal dan Neonatal. Cetakan 8. Jakarta : Yayasan Bina Pustaka.

Rochjati, P. 2003. Skrining Antenatal Pada Ibu Hamil. Surabaya : FK UNAIR

Rochmawati, Putri N. 2013. Faktor-faktor yang mempengaruhi abortus di rumah sakit umum pusat dr.Soeradji tirto negoro klaten. Http://eprints.ums.ac.id/25655/11/ NASKAH_PUBLIKASI.pdf. Diakses 22/12/2016 RSUD Jombang. 2016. Data ibu bersalin di Ruang Ponek: Rsud Jombang

Rukiyah, A.Y,dkk. 2010. Asuhan Kebidanan IV (Ppatologi Kebidanan). Jakarta : Trans Info Media

Sarwono, Jonahan. 2010. Pintar Menulis Karya Ilmiah Kunci Sukses dalam Menulis Ilmiah. Yogyakarta : C.V Andi Offset

Saryono, 2011. Metedologi Penelitian Kesehatan. Jogjakarta : Mitra Cendeka

Shandra Riestya Prihandini dkk, 2016. Usia Reproduksi Tidak Sehat Dan Jarak Kehamilan Yang Terlalu Dekat Meningkatkan Kejadian Abortus Di Rumah Sakit Tentara Dokter Soedjono Magelang. http://ejournal.poltekkessmg.ac.id/ojs/index.php/jurkeb/arti cle/view/1147/408.

diakses

21/01/2017

Sloane \& Benedict. 2009. Petunjuk Lengkap Kehamilan. Alih Bahasa, Anton Adiwiyoto. Dalam jurnal Asuhan kebidanan komprehensif. http://chiyapuri.blogspot.co.id/201 6/04/jurnal-asuhan-kebidanankomprehensif.html. diakses $25 / 03.17$

Stikes Pemkab Jombang. 2016. Pedoman Penulisan Karya Tulis Ilmiah dan Skripsi bagi Diploma-Sarjana. Jombang : Stikes Pemkab Jombang

Sudarti, dan Sukarni I. 2014 Patologi Kehamilan, Persalinan, Nifas, dan Neonatus Resiko Tinggi, Edisi cetakan: I. Yogyakarta : Nuha Medika

Sugiyono. 2015. Statistika untuk Penelitian. Bandung : Alfabeta

Sujarweni, Wiratna.2014. Metode Penelitian Keperawatan Yogyakarta : Gava Media

Suryono. 2010. Metodologi Penelitian Kesehatan. Jogjakarta : Mitra Cendikia Sehat

Tiara. 2011. Konsep Abortus Spontan. Online

https://tiara3arza.wordpress.com/2011/06/3 0/abortus-inkomplit/.Diakses $16 / 02 / 2017$

Wiknjosastro, Hanifa. 2010. Ilmu Kebidanan. Jakarta: Yayasan Bina Pustaka Sarwono

Yulichati, dan RenitaRatna S, 2014. Jurnal Asuhan Kebidanan Pada Ibu Post Kuretase di Ruang Ponek Rumah Sakit Umum Jombang.

http://jurnalbidan.stikespemkabjombang.ac .id/index.php/maret2016/article/vie w/29/28. Diakses 28/12/2016

Yulifah, rita dan Surahmindari. 2013 Konsep kebidanan, Edisi Jakarta Selatan: Salemba Medika. 